\title{
Psychometric properties of the Polish version of the Self-Pluralism Scale (SPS)
}

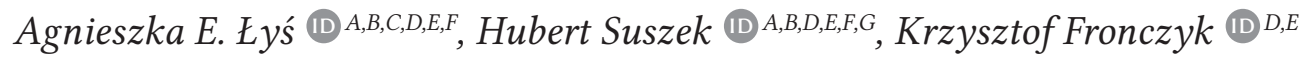 \\ Faculty of Psychology, University of Warsaw, Warsaw, Poland
}

\section{BACKGROUND}

The Self-Pluralism Scale (SPS) measures the declared degree of self-pluralism, visible already in William James's works. Self-pluralism refers to the degree to which one perceives oneself as typically feeling, behaving, and being different, in different situations, and at different times. The purpose of the current study was to evaluate the psychometric properties of the Polish version of the SPS.

\section{PARTICIPANTS AND PROCEDURE}

A total of 1747 participants ( $67 \%$ were women) between the ages of 15 and 70 years completed the SPS along with measures of self-concept inconsistency, self-concept differentiation, dissociative experiences, internal dialogical activity, personality, and social desirability.

\section{RESULTS}

Internal reliability and test-retest reliability were high. The full version has too low indices of fit whereas the brief, 10-item version fits the data well. As indicators of the convergent validity, a positive correlation of SPS with self-concept inconsistency, self-concept differentiation, dissociative experiences, internal dialogical activity and neuroticism and a negative correlation with agreeableness and social desirability were found.

\section{CONCLUSIONS}

The results suggest that the brief, 10-item version is more valid than the full, 30-item version. The tool may be used for scientific research concerning self-pluralism. After collecting data from a sample that would allow norms to be constructed, the tool may also be useful for individual diagnosis.

\section{KEY WORDS}

self-pluralism scale; self-concept; confirmatory factor analysis

Corresponding Author - Agnieszka E. Łyś, Faculty of Psychology, University of Warsaw, 5/7 Stawki Str., 00-183 Warsaw, Poland, e-mail: agnieszka.lys@psych.uw.edu.pl

AUthors' CONTRIBUtion - A: Study design · B: Data collection · C: Statistical analysis · D: Data interpretation .

E: Manuscript preparation · F: Literature search · G: Funds collection

to Cite this ARTicle - Łyś, A. E., Suszek, H., \& Fronczyk, K. (2022). Psychometric properties of the Polish version

of the Self-Pluralism Scale (SPS). Current Issues in Personality Psychology, 10(2), 153-163.

RECEIVED 23.01.2021 · REVIEWED 10.03.2021 · ACCEPTED 22.05.2021 · PUBLISHED 01.07.2021 


\section{BACKGROUND}

William James distinguished two aspects of the self as object and subject: the me and the $I$ - self as known and self as knower. He then divided the me part of the self into further parts: the material Self, the social Self, the spiritual Self and the pure Ego (James, 1890/2018). Since then, many scholars have focused on the pluralism of the self as known. In social and personality psychology, there is a converging understanding of the self as a multifaceted knowledge structure (Oyserman, 2004). A vision of personality as a multiple structure can also be found in Freud's and Jung's works. Freud claimed the division of personality into id, ego and superego (Freud, 1923/2010), while Jung accentuated the complexes and archetypes as parts of the Self (Jung, 1934/1954).

Currently the notion that people possess multiple selves, which are accessible in different situations and contexts, has received considerable attention. One group of theories deals with the existence of some universal components of the self that are common among all people. Examples of such components are the personal and the social identity (Tajfel \& Turner, 1979), private and public self (Fenigstein et al., 1975), private, public and collective self (Triandis, 1989), as well as real, ideal and ought self (Higgins, 1987). Another line of research postulates the existence of idiographic components of the self. The fragmentation of the self is unique for each individual (Martindale, 1980; Rosenberg, 1997; McConnell, 2011). Some proposed constructs are self-schemata (Markus, 1977), possible selves (Markus \& Nurius, 1986) and undesired selves (Ogilvie, 1987). Metaphorically speaking, each person has his own family of selves (Cantor \& Kihlstrom, 1987) or community of selves (Mair, 1977). Wilson et al. (2017) demonstrated that people exhibit significant within-person variability in Big Five traits and it cannot be explained entirely by affective states. Moreover, computational modeling also demonstrates within-person variability in personality states (Read et al., 2017).

\section{SELF-PLURALISM AND PSYCHOTHERAPY}

Self-multiplicity is not only interesting from a scientific point of view but has also been acknowledged in the domain of psychotherapy. Some psychotherapeutic approaches describe the disorders as a result of problems in relationships between different parts of a personality. This perspective is present in the Voice Dialogue approach (Stone \& Stone, 1993), dialectical constructivist approach (Cooper \& Crutchers, 1999), Internal Family Systems Therapy (Schwartz, 1999) and some currents referring to subpersonalities (Cooper \& Crutchers, 1999). In these approaches the aim of psychotherapy is not uniformity of the Self, but rather a balance between its different parts.

\section{HOW TO MEASURE SELF-PLURALISM?}

A few attempts have been made to describe individual differences in the extent to which people exhibit differences across contexts. In regard to this, there are two approaches to the individual differences in self-multiplicity. The first is the structure of the self, which is based on the assumption that the individual does not have conscious access to the structure of their self (e.g., Linville, 1985). The second concerns self-reported self-pluralism and is based on the belief that the individual is able to consciously assess the complexity of their self. The tool that we present in this article emerges from the second approach.

In the psychology of individual differences there are some constructs that are similar to self-pluralism. One of them is self-concept differentiation, which is defined as "the tendency to see oneself as having different personality characteristics across one's roles" (Donahue et al., 1993, p. 834). It is measured with a questionnaire where the participant receives a list of adjectives and is told to assess the extent to which each of them describes himself/herself in different roles (Donahue et al., 1993). While self-concept differentiation describes the extent to which persons exhibit a variety of fixed personality traits across a fixed collection of roles, self-pluralism represents a more general, idiographic and role-independent feature of the self-concept.

Another similar construct is self-concept clarity. Campbell et al. (1996) defined it as "the extent to which the contents of an individual's self-concept (e.g., perceived personal attributes) are clearly and confidently defined, internally consistent, and temporally stable" (Campbell et al., 1996). Nevertheless, McReynolds et al. (2000) underscore that self-concept clarity primarily concerns the consistency of identity, whereas self-pluralism concerns the perception of someone's own behavior rather than identity. Campbell et al. (1996) constructed a questionnaire to measure self-concept clarity (sample item: "My beliefs about myself often conflict with one another").

Another similar construct is sense of self, which can be strong or weak. According to Flury and Ickes (2007), a weak sense of self has the following components: a lack of understanding of oneself, sudden shifts in feelings, opinions, and values, the tendency to confuse one's feelings, thoughts, and perspectives with those of others and the feeling that one's very existence is tenuous. They constructed a 12 -item Sense of Self Scale. The sense of self is related to the abovementioned constructs, but we should take into 
account that a weak sense of self is a clinical phenomenon, characteristic, for example, of people with borderline personality disorder, whereas the other mentioned constructs are not.

\section{CORRELATES OF SELF-PLURALISM}

There is some evidence for a link between self-concept differentiation and maladjustment. However, this link depends on the culture - in individualistic cultures, the association between self-concept differentiation and maladjustment is the strongest (Bleidorn \& Ködding, 2013). There is also some evidence that consistently ascribing positive traits to the Self in different situations predicts well-being, whereas there is no such regularity in the case of consistent responses to negative traits (Cohen et al., 2014; Locke, 2006). On the other hand, there is some evidence that self-complexity may work as a buffer against the adverse consequence of stress (Linville, 1987). Magee et al. (2018) demonstrated a curvilinear relationship between adjustment and personality variability - according to their analysis, individuals with a low or high level of adjustment have a higher level of personality variability than individuals with a medium level of adjustment. Moreover, according to Churchyard et al. (2014), within-subject variance in some personality traits is related to positive psychological outcomes whereas within-subject variance in other personality traits is related to negative psychological outcomes.

As we can see, the relationship between self-pluralism and adjustment depends on other variables, e.g., culture. Studies concerning this relationship are correlational; thus, we cannot draw any conclusions concerning a cause-and-effect relationship. Moreover, the uniformity of a personality does not always mean that the individual in question is healthy and functions well. Ross (1999) describes the notion of pathological pseudounity where declared uniformity of the personality leads to suppressing many aspects of personality that may be useful and should be integrated instead of being eliminated.

We should also take into account the contemporary context. Some researchers emphasize that the uniformity of the personality may no longer be adaptive. According to Bauman (1998), fluidity and instability are important features of present times. Thus, the relationship between self-pluralism and adjustment is very complex.

\section{SELF-PLURALISM SCALE (SPS)}

The Self-Pluralism Scale (SPS) measures the declared degree of self-pluralism. The SPS, constructed by McReynolds et al. (2000), and consisting of 30 items on a nominal scale (yes/no), measures the extent to which the individual perceives his personality and behavior as different in various contexts and situations. Its internal consistency is high $(\alpha=.90)$. However, we should also pay attention to a significant, negative correlation between SPS and socially desirable responding. This result may suggest that people who have a high level of need for social approval may have a higher level of self-pluralism than they present when answering the items of the SPS. McReynolds et al. (2000) also identified positive correlations between self-pluralism and college maladjustment, dissociative experiences, anxiety traits, neuroticism and openness as well as negative correlations between self-pluralism and age, self-esteem, agreeableness, conscientiousness and ego strength. Altrocchi (1999) also constructed a short version of the SPS (Brief Self-Pluralism Scale, SPS-10). Its internal consistency is high $(\alpha=.83)$.

The aim of the current study was to develop a Polish version of the SPS-30 and SPS-10. In our study we aimed to assess its reliability and validity. We expected that it would have a one-factor structure, like its original version. In order to evaluate its convergent validity, we assessed its correlation with self-concept inconsistency, dissociative experiences, internal dialogical activity and neuroticism. We expected that the correlations would be positive. We also aimed to determine whether its results are prone to social desirability bias.

\section{PARTICIPANTS AND PROCEDURE}

\section{PARTICIPANTS}

A total of 1747 graduates and undergraduates of the University of Warsaw participated in the study. Their ages ranged from 18 to 70 years $(M=25.06$, $S D=7.79)$; $67 \%$ of them were female. Participants were tested individually. The order of the questionnaires was rotated. Participation in the study was not remunerated. The study was approved by the Ethics Committee of the Faculty of Psychology at the University of Warsaw.

\section{MEASURES}

The original version of the SPS was translated into Polish by a professional translator, then it was backtranslated by a second translator to ensure comparability and equivalence in meaning. Neither of the translators was aware of the content of this study. Discrepancies were discussed and agreed upon by both the authors and the back-translator.

Self-concept inconsistency (SCI) was measured with the procedure used by Boucher and O’Down (2011). 
The Polish version of this procedure consists of 40 traits, arranged as 20 contradictory pairs (e.g., closed-open, sensitive-callous, passive-active, sociable-withdrawn, brutal-sensitive, spontaneousrestrained, silent-talkative). The adjectives were randomly ordered. The participants rated on a 7-point Likert scale to what extent the adjectives fit them. The antonyms were selected in a previous pilot study $(N=67)$. For each pair an inconsistency score using the following formula was computed: $\left(2{ }^{*} \mathrm{~S}+1\right) /(\mathrm{S}+\mathrm{L}+2)$, where $\mathrm{S}$ is the smaller and $\mathrm{L}$ the larger value (negative acceleration model; Scott, 1966). Larger values indicate greater inconsistency. The index of global self-concept inconsistency was calculated as the mean of all pairs' inconsistencies. Internal consistency was .87 .

Self-concept differentiation (SCD) was measured with the Self-Concept Inconsistency Questionnaire (Styła et al., 2010), which is based on the procedure proposed by Donahue et al. (1993). It was constructed to assess individual differences in the tendency to see oneself as having different personality characteristics across one's roles. Participants' task is to assess on a 7-point Likert-type scale the intensity of seven adjectives describing personality traits (e.g., "active") for each of five different social roles: student, friend, romantic partner, son or daughter, and worker. To obtain the total score, one has to calculate the standard deviation across all five social roles for each adjective separately and then compute the mean. A high score represents high inconsistency among roles. The internal consistency is .75 and the test-retest stability is .73. The internal consistency of the scale in this study was .91 .

The frequency of dissociative experiences was measured with the 28-item Dissociative Experiences Scale II (DES), developed by Carlson and Putnam (1993). Participants indicate on an 11-point scale how often particular experiences happen to them. The final score is an average of the 28 questions ranging from 0 to 100 . The DES has three subscales (Ross et al., 1995) called Amnesia (8 items primarily measuring amnesia), Depersonalization (6 items measuring feelings of unreality about oneself or the environment), and Absorption (9 items primarily measuring absorption and imaginative involvement). The Polish version of the scale displays an internal consistency of .91 (Gołąb, 1999; Suszek, 2005). The internal consistency of the scale in this study was .92.

Internal dialogical activity in everyday life was measured with the Internal Dialogical Activity Scale (IDAS; Oleś, 2009; Oleś \& Puchalska-Wasyl, 2011). The scale consists of 47 items and 7 subscales. It allows assessment of the intensity of general dialogical activity (general score) and seven kinds of internal dialogues: (1) Pure Dialogical Activity (PDA; e.g., "I converse with myself"); (2) Identity
Dialogues (ID; e.g., "Sometimes I debate with myself about who I really am"); (3) Supportive Dialogues (SD; e.g., "In some stressful situations, I attempt to calm myself with my thoughts"; (4) Ruminative Dialogues (RD; e.g., "After failures, I blame myself in my thoughts and discuss how the failures could have been avoided"; (5) Confronting Dialogues (CD; e.g., "Sometimes I think that my 'good' side argues with my 'bad' side"; (6) Simulation of Social Dialogues (SSD; e.g., "Sometimes I continue a conversation with other people in my mind"; (7) Taking a Point of View (TPV; e.g., "Often in my thoughts I use the perspective of someone else"). The internal consistency for the total score is .93 and between .64 and .82 for the subscales. The test-retest stability for the total score is .81 and between .69 and .81 for the subscales. The internal consistency in this study was .95 for the total score and between .79 and .86 for the subscales.

The Big Five personality traits were measured with the NEO-Five Factor Inventory (NEO-FFI; Costa $\&$ McCrae, 1992). It is a general self-report measure of personality reflecting the dimensions: neuroticism, extraversion, openness to experience, conscientiousness, and agreeableness. The Polish version was adapted by Zawadzki and colleagues (1998). It consists of 60 items, to which participants respond on a 5 -point scale ranging from strongly disagree to strongly agree. Each trait is assessed with 12 items, which are added together to form a scale. They have a range of 0-48. The trait scales have an internal reliability between .68 (agreeableness and openness to experience) and .82 (conscientiousness). The internal consistency in this study was between .72 (agreeableness) and .86 (extraversion).

Social desirability was assessed with the Marlowe-Crowne Social Desirability Scale (MCSDS; Crowne \& Marlowe, 1960). It was designed to assess the extent to which people describe themselves in favorable terms (e.g., "I'm always kind even with unpleasant people"). The scale consists of 33 true-false items. Scores range from 0 to 33, with higher scores reflecting greater social desirability. The Polish version of the scale displays an internal consistency of .69 and test-retest reliability of .87 (Siuta, 1989). The reliability of the scale in this study was .75.

All participants filled in the Polish version of the SPS-30, and members of different subsamples of the entire sample additionally filled in some of the abovementioned instruments: IDAS $(N=140)$, SCI $(N=150)$, DES $(N=178)$, NEO-FFI $(N=51)$, MCSD $(N=134)$.

\section{RESULTS}

The descriptive statistics of the score distribution of SPS-30 are presented in Table 1. 
Agnieszka E. Łyś, Hubert Suszek, Krzysztof Fronczyk

Table 1

Descriptive statistics of the score distribution of SPS-30 and SPS-10

\begin{tabular}{lcccccc}
\hline & Mean & Median & Variance & SD & Skewness & Kurtosis \\
\hline SPS-30 & 11.96 & 11 & 48.065 & 6.93 & 0.46 & -0.72 \\
SPS-10 & 2.68 & 2 & 7.48 & 2.74 & 0.90 & -0.27 \\
\hline
\end{tabular}

Table 2

Confirmatory factor analysis - SPS-30 and SPS-10

\begin{tabular}{lcccccc}
\hline & $\chi^{2}$ & $d f$ & CFI & TLI & RMSEA & SRMR \\
\hline SPS-30 & $2947.73^{* *}$ & 405 & .78 & .77 & $.063(90 \% \mathrm{Cl}: .061, .065)$ & .054 \\
SPS-10 & $236.39^{* *}$ & 35 & .96 & .94 & $.057(90 \% \mathrm{Cl}: .050, .064)$ & .034 \\
\hline Note. ${ }^{* *} p<.001$. & & & & & &
\end{tabular}

\section{CONFIRMATORY FACTOR ANALYSIS}

In order to verify whether the one-factor model proposed by McReynolds et al. (2000) fits our data well, we conducted a confirmatory factor analysis. Taking into account that the distribution does not meet the requirement of multivariate normality, we chose a maximum likelihood robust method of estimation and we used bootstrapping. The parameters of the model are presented in Table 2 .

As we can see, the comparative fit index (CFI) and Tucker-Lewis index (TLI) do not reach the threshold of acceptability suggested by Awang (2012), which is .9. Thus we conducted an exploratory factor analysis in order to determine whether there are any other models of factor structure that we should consider.

\section{EXPLORATORY FACTOR ANALYSIS}

The factor loadings are in Table 3. As can be seen, there are 6 factors, but most of the variance (23\%) is explained by the first factor. In order to obtain a model that fits the data better we decided to create a brief, 10-item version of the questionnaire. We chose 10 items which load the first factor to the highest degree.

\section{CONFIRMATORY FACTOR ANALYSIS - BRIEF VERSION}

The parameters of the model are presented in Table 4.

The CFI of the brief version reaches the threshold (0.95) which indicates that the model is a good fit. The TLI of the brief version reaches the threshold $(0.90)$ which indicates that the model is satisfactory.
Other parameters also suggest that the model fits the data well (Awang, 2012; Hu \& Bentler, 1999).

\section{RELIABILITY OF THE SCALE}

Both versions of the scale - the 30-item and the 10-item one - have a good level of internal consistency (respectively, $\alpha=.89$ and $\alpha=.83$ ). We also tested absolute stability by administering the scale to 88 randomly selected participants one month after the main part of the study. The results suggest that the scores of both the 30 -item and the 10-item version are stable (respectively, rho $=.86$ and rho $=.79, p<.01$ ).

\section{SPS-30, SPS-10 AND OTHER MEASURES}

In order to evaluate the convergent validity of the tool we also analyzed the correlation between SPS-30, SPS-10 and other tools measuring similar constructs: Self-concept inconsistency (SCI), Self-concept differentiation (SCD), Dissociative Experiences Scale II (DES), Internal Dialogical Activity Scale (IDAS). A positive correlation of SPS-30 and SPS-10 with all of these scales was found. We also examined the correlation between SPS-30, SPS-10 and the Big Five personality factors, measured by the NEO-FFI scale. A correlation between self-pluralism and two of the Big Five factors, neuroticism and agreeableness, was observed. The correlation with neuroticism was positive and that with agreeableness was negative (although in the case of SPS-10 it was not significant). We also found a negative correlation with age. Also, compared to men $(M=11.51, S D=6.56)$, women $(M=12.20, S D=7.11)$ had a significantly higher level of self-pluralism $(t(1219)=2.00, p=.045)$. 
Table 3

Factor loadings - exploratory factor analysis

\begin{tabular}{|c|c|c|c|c|c|c|}
\hline Item & 1 & 2 & 3 & 4 & 5 & 6 \\
\hline $\begin{array}{l}\text { 1. Ludzie, którzy znają mnie dobrze, powiedzieliby, że } \\
\text { jestem dość przewidywalny. / People who know me } \\
\text { well would say l'm pretty predictable. (R) }\end{array}$ & & & & & .362 & -.170 \\
\hline $\begin{array}{l}\text { 2. Miewam dosyć duże huśtawki nastroju. / I have } \\
\text { fairly big mood swings. }\end{array}$ & & & & .670 & .127 & \\
\hline $\begin{array}{l}\text { 3. Czasami zaskakuję sam siebie moim sposobem } \\
\text { działania i odczuwania. / Sometimes I'm surprised } \\
\text { at myself for the ways I feel or the things I do. }\end{array}$ & & & & & .582 & \\
\hline $\begin{array}{l}\text { 4. Zachowuję się i odczuwam zasadniczo w ten } \\
\text { sam sposób niezależnie od tego, czy znajduję się } \\
\text { w domu, w pracy, czy wśród przyjaciół. / I act and } \\
\text { feel essentially the same way whether at home, } \\
\text { at work, or with friends. (R) }\end{array}$ & -.106 & .594 & & & & \\
\hline $\begin{array}{l}\text { 5. Czasami zachowuję się tak różnie w różnych } \\
\text { sytuacjach, że ludzie mieliby trudność z rozpoznaniem } \\
\text { mnie jako tej samej osoby. / Sometimes I behave so } \\
\text { differently in different situations that people would } \\
\text { have difficulty recognizing me as the same person. }\end{array}$ & .267 & .319 & & & .179 & \\
\hline $\begin{array}{l}\text { 6. Od czasu do czasu zachowuję się w sposób odmienny } \\
\text { do mojego normalnego ja. / I occasionally behave } \\
\text { in a way unlike my normal self. }\end{array}$ & & .257 & & & .242 & .204 \\
\hline $\begin{array}{l}\text { 7. Jestem taką samą osobą bez względu na to, z kim } \\
\text { przebywam. / I'm the same sort of person regardless } \\
\text { of whom I'm with. (R) }\end{array}$ & & .731 & & & & \\
\hline $\begin{array}{l}\text { 8. Zdarzało się, że nie pamiętałem szeregu rzeczy, które } \\
\text { zrobiłem, lub tego, jak się zachowywałem. / There } \\
\text { have been times when I did not remember a series of } \\
\text { things that I had done, or the way that I had behaved. }\end{array}$ & .155 & & & & .251 & .122 \\
\hline $\begin{array}{l}\text { 9. Czasami czuję się jak dwie osoby (lub więcej) w tej } \\
\text { samej skórze. / Sometimes I feel like two (or more) } \\
\text { persons under the same skin. }\end{array}$ & .493 & & & & .129 & .140 \\
\hline $\begin{array}{l}\text { 10. Chociaż zachowuję się różnie w różnych sytuacjach } \\
\text { (np. na imprezie, w pracy, w domu), wewnątrz } \\
\text { zawsze czuję się prawie tak samo. / Though I behave } \\
\text { differently in different situations (for example, } \\
\text { at a party, at work, at home) I always feel much } \\
\text { the same inside. (R) }\end{array}$ & & & .420 & & & \\
\hline $\begin{array}{l}\text { 11. Najlepiej mi idzie, gdy zachowuję się i odczuwam } \\
\text { w różnych momentach jak całkowicie inna osoba. / } \\
\text { I get along best when I act and feel like a totally } \\
\text { different person at different times. }\end{array}$ & .441 & & & & & \\
\hline $\begin{array}{l}\text { 12. Jeśli różne osoby, które dobrze mnie znają, miałyby } \\
\text { mnie opisać, to opisy te byłyby prawie takie same. / } \\
\text { If each of the different people who know me well } \\
\text { were asked to describe me, the descriptions would } \\
\text { be much the same. (R) }\end{array}$ & .138 & .381 & .131 & & & -.129 \\
\hline
\end{tabular}


Table 3

Table 3 continued

\begin{tabular}{|c|c|c|c|c|c|c|}
\hline Item & 1 & 2 & 3 & 4 & 5 & 6 \\
\hline $\begin{array}{l}\text { 13. Mój nastrój podlega tylko drobnym zmianom. / } \\
\text { I have only minor changes in mood. (R) }\end{array}$ & & & & .772 & & \\
\hline $\begin{array}{l}\text { 14. Jedna strona mojej osobowości różni się całkiem od } \\
\text { drugiej strony. / One side of my personality is quite } \\
\text { different from the other side. }\end{array}$ & .524 & & & .104 & & \\
\hline $\begin{array}{l}\text { 15. Dzień w dzień jestem pod każdym względem taką } \\
\text { samą osobą. / I am the same kind of person in every } \\
\text { way, day in and day out. (R) }\end{array}$ & & .432 & & .215 & & \\
\hline $\begin{array}{l}\text { 16. Niektóre moje strony tak różnią się od siebie, że } \\
\text { nadałem im odmienne nazwy. / There are parts } \\
\text { of me that are so different from each other that } \\
\text { I have given them different names. }\end{array}$ & .573 & & & & & \\
\hline $\begin{array}{l}\text { 17. Prawie nigdy nie dziwi mnie sposób, w jaki zachowuję } \\
\text { się i odczuwam. / I am almost never surprised at the } \\
\text { way I behave or feel. (R) }\end{array}$ & & .140 & .113 & .155 & .281 & \\
\hline $\begin{array}{l}\text { 18. Czasami czuję się wewnątrz inną osobą niż kiedy } \\
\text { indziej, ale ludzie wydają się tego nigdy nie } \\
\text { dostrzegać. / I sometimes feel inside like a different } \\
\text { person than at other times, but this never seems } \\
\text { apparent to other people. }\end{array}$ & .131 & & & & .117 & .460 \\
\hline $\begin{array}{l}\text { 19. Ludzie, którzy mnie znają, twierdzą, że moje } \\
\text { zachowanie zmienia się z sytuacji na sytuację. / } \\
\text { People who know me would say that my behavior } \\
\text { changes from situation to situation. }\end{array}$ & .374 & & & & .137 & -.229 \\
\hline $\begin{array}{l}\text { 20. Moja osobowość jest zawsze taka sama niezależnie od } \\
\text { tego, z kim przebywam i w jakiej sytuacji się znajduję. / } \\
\text { My personality is always the same regardless of } \\
\text { whom I'm with or the situation I'm in. (R) }\end{array}$ & & .556 & & & & .121 \\
\hline $\begin{array}{l}\text { 21. Gdybym miał opisać siebie szczegółowo, musiałbym } \\
\text { użyć dwóch (lub więcej) różnych opisów. / If I were } \\
\text { to describe myself in detail l'd have to use two } \\
\text { (or more) different descriptions. }\end{array}$ & .459 & .133 & & & .106 & \\
\hline $\begin{array}{l}\text { 22. Ludzie, którzy znają mnie dobrze, powiedzieliby, } \\
\text { że zachowuję się całkiem odmiennie w różnych } \\
\text { okresach czasu. / People who know me well would } \\
\text { say I act quite differently at different times. }\end{array}$ & .370 & .172 & & & .226 & \\
\hline $\begin{array}{l}\text { 23. Pomimo że zmieniam się nieco od czasu do czasu, } \\
\text { na ogół czuję się prawie tak samo. / Though I vary } \\
\text { somewhat from time to time in general I always feel } \\
\text { much the same. }(\mathrm{R})\end{array}$ & & & .641 & & & \\
\hline $\begin{array}{l}\text { 24. Posiadam dwie (lub więcej) odmienne osobowości } \\
\text { i w danej chwili jestem jedną bądź drugą. / I have } \\
\text { two (or more) distinct personalities and at any given } \\
\text { time I'm either one or the other. }\end{array}$ & .777 & & & & & \\
\hline $\begin{array}{l}\text { 25. Zmieniam się jedynie nieznacznie od czasu do czasu } \\
\text { lub z sytuacji na sytuację. / I change very little from } \\
\text { time to time, or from one situation to another. (R) }\end{array}$ & & & .529 & & & \\
\hline
\end{tabular}


Table 3

Table 3 continued

\begin{tabular}{|c|c|c|c|c|c|c|}
\hline Item & 1 & 2 & 3 & 4 & 5 & 6 \\
\hline $\begin{array}{l}\text { 26. Czasami czuję się dosyć odmiennie od tego, jak } \\
\text { czuję się kiedy indziej, ale ogólnie czuję się prawie } \\
\text { tak samo. / Sometimes I feel pretty different from } \\
\text { the way I feel at other times, but generally I feel } \\
\text { much the same way. (R) }\end{array}$ & -.104 & & .618 & & & \\
\hline $\begin{array}{l}\text { 27. Zdarzało się, że jednego dnia czułem się jak } \\
\text { kompletnie inna osoba niż dzień wcześniej. / There } \\
\text { have been times when I felt like a completely } \\
\text { different person from what I was the day before. }\end{array}$ & .357 & & & & .167 & .201 \\
\hline $\begin{array}{l}\text { 28. Ludzie, którzy znają mnie dobrze, powiedzieliby, że } \\
\text { zachowuję się w zasadzie tak samo niezależnie od } \\
\text { okoliczności. / People who know me well would say } \\
\text { I behave basically the same in all circumstances. (R) }\end{array}$ & & .445 & .120 & & & -.161 \\
\hline $\begin{array}{l}\text { 29. Czasem miewam dylematy w związku z tym, czy } \\
\text { być takim, czy innym typem osoby. / I sometimes } \\
\text { have conflicts over whether to be one kind } \\
\text { of a person or a different kind. }\end{array}$ & .207 & .109 & & & & .168 \\
\hline $\begin{array}{l}\text { 30. Przechodzę przez dni raczej z poczuciem wewnętrznej } \\
\text { równowagi. / I go along on a pretty even keel from } \\
\text { day to day. }(\mathrm{R})\end{array}$ & .128 & & .204 & .342 & & \\
\hline
\end{tabular}

\section{Table 4}

Correlations: SPS-30, SPS-10, Self-concept inconsistency (SCI), Self-concept differentiation (SCD), Dissociative Experiences Scale II (DES), Internal Dialogical Activity Scale (IDAS), NEO-Five Factor Inventory (NEO-FFI), Marlowe-Crowne Social Desirability Scale (MCSDS)

\begin{tabular}{lcc}
\hline & SPS-30 & SPS-10 \\
\hline SPS-30 & 1 & $.87^{* *}$ \\
SPS-10 & $.87^{* *}$ & 1 \\
SCI & $.28^{* *}$ & $.19^{*}$ \\
SCD & $.38^{* *}$ & $.33^{* *}$ \\
DES & $.35^{* *}$ & $.35^{* *}$ \\
IDAS & $.48^{* *}$ & $.45^{* *}$ \\
Extraversion & .07 & .10 \\
Neuroticism & $.30^{*}$ & $.36^{* *}$ \\
Openness & .10 & .10 \\
Conscientiousness & -.08 & -.03 \\
Agreeableness & $-.23^{*}$ & -.22 \\
MCSDS & $-.43^{* *}$ & $-.32^{* *}$ \\
Age & $-.26^{* *}$ & $-.22^{* *}$ \\
\hline Note. ${ }^{*} p<.05 ;{ }^{* *} p<.01$. & &
\end{tabular}

In order to find out whether the tool is susceptible to social desirability bias, we assessed the correlation between SPS-30, SPS-10 and the Marlowe-Crowne Social Desirability Scale. We found a negative correlation between self-pluralism and social desirability. All the correlations are presented in Table 5.

\section{DISCUSSION}

Our research demonstrated that SPS-30 includes more than one factor. In order to ensure the construct validity of the tool we decided to create a brief version which includes one factor, which is consistent with the theory underlying the original version, according to which self-pluralism is a onefactor construct. It turned out that the brief version (SPS-10) fits the data better than SPS-30, and thus we can suppose it has a higher level of construct validity. The positive correlations between SPS-30, SPS-10 and the tools measuring similar constructs confirm the convergent validity of both versions of the tool. The positive correlations between SPS-30, SPS-10 and neuroticism as well as the negative correlation with agreeableness also demonstrate its convergent validity. Nevertheless, these correlations are not strong, and the correlation between SPS-10 and agreeableness is not significant, which may stem from the small size of the subsample of partici- 
pants who filled out the NEO-FFI. Contrary to the original one, the Polish version of the tool does not correlate significantly with openness to experience and with conscientiousness. Inter-cultural differences may play a role here. American culture is more individualistic than Polish (Hofstede, 2001; Hofstede et al., 2010), and thus in the USA people may have better opportunities to express their self-pluralism, for example, by being more open to experience than people who have a low degree of self-pluralism. The lack of correlation between self-pluralism and conscientiousness is also puzzling. This may result from the lower level of conscientiousness among Polish people - there is evidence that people from Eastern Europe are less conscientious than people from North America (Schmitt et al., 2007). However, these hypotheses need further verification.

In our sample, women had a significantly higher level of self-pluralism than men. There were no significant gender differences in the American sample studies of McReynolds et al. (2000). Cross-cultural differences may play a role here, too. There is some evidence that Anglo-Saxon countries have relatively low levels of sexism towards men (Glick et al., 2004; Zawisza et al., 2012). Thus, in Poland men may feel greater pressure to fit the traditional pattern of masculinity and, consequently, to be consistent and avoid being unstable, which may seem like a sign of weakness. Nevertheless, this hypothesis needs further investigation.

The study contains limitations that are important to acknowledge. First, the fact that the data were collected in one setting limits the generalizability of the results. The study was carried out with a sample of university students in one Polish city. The study participants were highly educated and relatively young; thus we should interpret the negative correlation between self-pluralism and age very cautiously. Further validation studies should be conducted to provide additional evidence within the demographically diverse populations of different regions of Poland.

Second, as self-report measures were used in the study, there was no objective measure of how the contents of an individual's self-concept change in different contexts. Inclusion of such a measure in future studies would be useful. A negative correlation between the Self-Pluralism Scale and the MarloweCrowne Social Desirability Scale exists both in the case of the Polish version and the original version. It suggests that different, non-declarative measures of self-pluralism, for example, based on the Implicit Association Test, are also needed. However, the psychometric parameters of the SPS-10 demonstrate that it is a valid and reliable tool for measuring self-reported self-pluralism, whereas the full version of the tool needs further investigation. The shorter version can then be used for studies investigating the predictors and correlates of self-reported self-pluralism. As we mentioned above, self-pluralism is an important issue not only for personality psychology but also for psychotherapy. Thus, after collecting data from a sample that allows norms to be constructed, the tool may also be useful for individual diagnosis.

\section{FUNDING}

This study was funded by the National Science Centre, Poland (grant number 2016/23/B/HS6/00318).

\section{RefERENCES}

Altrocchi, J. (1999). Individual differences in pluralism in self-structure. In J. Rowan \& M. Cooper (Eds.), The plural self. Multiplicity in everyday life (pp. 168-182). Sage.

Awang, Z. (2012). Structural equation modeling using Amos graphic. UiTM Press.

Bauman, Z. (1998). Globalization: The human consequences. Columbia University Press.

Bleidorn, W., \& Ködding, C. (2013). The divided self and psychological (mal) adjustment - a meta-analytic review. Journal of Research in Personality, 47, 547-552. https://doi.org/10.1016/j.jrp.2013.04.009

Boucher, H. C., \& O’Dowd, M. C. (2011). Language and the bicultural dialectical self. Cultural Diversity \& Ethnic Minority Psychology, 17, 211-216. https://doi.org/10.1037/a0023686

Campbell, J. D., Trapnell, P. D., Heine, S. J., Katz, I. M., Lavallee, L. F., \& Lehman, D. R. (1996). Self-concept clarity: Measurement, personality correlates, and cultural boundaries. Journal of Personality and Social Psychology, 70, 141-156. https://doi.org/ 10.1037/0022-3514.70.1.141

Cantor, N., \& Kihlstrom, J. F. (1987). Personality and social intelligence. Prentice Hall.

Carlson, E., \& Putnam, F. (1993). An update on the dissociative experiences scale. Dissociation, 6, 16-27.

Churchyard, J. S., Pine, K. J., Sharma, S., \& Fletcher, B. (C). (2014). Same traits, different variance: Item-level variation within personality measures. Sage Open, 4, 215824401452263. https://doi.org/ $10.1177 / 2158244014522634$

Cohen, J. R., Spiegler, K. M., Young, J. F., Hankin, B. L., \& Abela, J. R. Z. (2014). Self-structures, negative events, and adolescent depression. The Journal of Early Adolescence, 34, 736-759. https://doi. org/10.1177/0272431613503217

Cooper, M., \& Cruthers, H. (1999). Facilitating the expression of subpersonalities: a review and analysis of techniques. In J. Rowan \& M. Cooper (Eds.), The plural self. Multiplicity in everyday life (pp. 198-212). Sage.

Costa, P. T., \& McCrae, R. R. (1992). Professional manual: Revised NEO Personality Inventory (NEO-PI-R) 
and NEO Five-Factor Inventory (NEO-FFI). Psychological Assessment Center.

Crowne, D., \& Marlowe, D. (1960). A new scale of social desirability independent of psychopathology. Journal of Consulting Psychology, 24, 349-354. https://doi.org/10.1037/h0047358

Donahue, E. M., Robins, R. W., Roberts, B. W., \& John, O. P. (1993). The divided self: Concurrent and longitudinal effects of psychological adjustment and social roles on self-concept differentiation. Journal of Personality and Social Psychology, 64, 834-846. https://doi.org/10.1037/0022-3514.64.5.834

Fenigstein, A., Scheier, M. F., \& Buss, A. H. (1975). Public and private self-consciousness: Assessment and theory. Journal of Consulting and Clinical Psychology, 43, 522-527. https://doi.org/10.1037/h0076760

Flury, J., \& Ickes, W. (2007). Having a weak versus strong sense of self: The Sense of Self Scale (SOSS). Self and Identity, 6, 281-303. https://doi. org/10.1080/15298860601033208

Freud, S. (1923/2010). The Ego and the Id. Martino Fine Books.

Glick, P., Lameiras Fernández, M., Fiske, S., Eckes, T., Masser, B., Volpato, Ch., Manganelli, A., Pek, J., Huang, L. L., Sakallı, N., Castro, Y., Pereira, M., Willemsen, T., Brunner, A., Six-Materna, I., \& Wells, R. (2004). Bad but bold: Ambivalent attitudes toward men predict gender inequality in 16 nations. Journal of Personality and Social Psychology, 86, 713728. https://doi.org/10.1037/0022-3514.86.5.713.

Gołąb, A. (1999). Przeżycia dysocjacyjne w życiu osób, które trafiły do więzienia [Dissociative experiences in the lives of people who ended up in prison]. Nowiny Psychologiczne, 4, 29-40.

Higgins, E. T. (1987). Self-discrepancy: a theory relating self and affect. Psychological Review, 94, 319340. https://doi.org/10.1037/0033-295X.94.3.319

Hofstede, G. (2001). Culture's consequences: Comparing values, behaviors, institutions, and organizations across nations. Sage Publications.

Hofstede, G., Hofstede G. J., \& Minkov, M. (2010). Cultures and organizations: Software of the mind (Revised and expanded 3rd edition). McGraw-Hill.

Hu, L., \& Bentler, P. (1999). Cutoff criteria for fit indices in covariance structure analysis: Conventional criteria versus new alternatives. Structural Equation Modeling, 6, 1-55. https://doi.org/ $10.1080 / 10705519909540118$

James, W. (1890/2018). The principles of psychology (Vol. 1). Retrieved from http://library.manipaldubai. com/DL/the_principles_of_psychology_vol_l.pdf

Jung, C. G. (1934/1954). Archetypes of the collective unconscious. In Collected works (Vol. 9.1). Routledge \& Kegan Paul.

Linville, P. W. (1985). Self-complexity and affective extremity: Don't put all eggs in one cognitive basket. Social Cognition, 3, 94-120. https://doi.org/10.1521/ soco.1985.3.1.94
Linville, P. W. (1987). Self-complexity as a cognitive buffer against stress-related illness and depression. Journal of Personality and Social Psychology, 52, 663-676. https://doi.org/10.1037/0022-3514.52.4.663

Locke, K. D. (2006). What predicts well-being: a consistent self-concept or a desirable self-concept? Journal of Social and Clinical Psychology, 25, 228-247. https://doi.org/10.1521/jscp.2006.25.2.228

Magee, C., Buchtel, E. E., Human, L. J., Murray, D. R., \& Biesanz, J. C. (2018). Is personality variability associated with adjustment? Journal of Research in Personality, 72, 22-43. https://doi.org/10.1016/j. jrp.2016.08.005

Mair, J. M. M. (1977). The community of self. In D. Bannister (Ed.), New perspectives in personal construct theory (pp. 125-149). Academic Press.

Markus, H. R. (1977). Self-schemata and processing information about the self. Journal of Personality and Social Psychology, 35, 63-78. https://doi.org/ 10.1037/0022-3514.35.2.63

Markus, H., \& Nurius, P. (1986). Possible selves. American Psychologist, 41, 954-969. https://doi. org/10.1037/0003-066X.41.9.954

Martindale, C. (1980). Subselves: The internal representation of situational and personal dispositions. In L. Wheeler (Ed.), Annual review of personality and social psychology (Vol. 1, pp. 193-218). Sage.

McConnell, A. R. (2011). The multiple self-aspects framework: Self-concept representation and its implications. Personality and Social Psychology Review, 15, 3-27. https://doi.org/10.1177/1088868310371101

McReynolds, P., Altrocchi, J., \& House, C. (2000). Selfpluralism: Assessment and relations to adjustment, life changes, and age. Journal of Personality, 68, 347-381. https://doi.org/10.1111/1467-6494.00100

Ogilvie, D. M. (1987). The undesired self: a neglected variable in personality research. Journal of Personality and Social Psychology, 52, 379-385. https:// doi.org/10.1037/0022-3514.52.2.379

Oleś, P. K. (2009). Czy głosy umysłu da się mierzyć? Skala Wewnętrznej Aktywności Dialogowej (SWAD) [Can the mind's voices be measured? The Internal Dialogical Activity Scale (IDAS)]. Przeglad Psychologiczny, 52, 37-50.

Oleś, P. K., \& Puchalska-Wasyl, M. (2011). Dialogicality and personality traits. In H. J. M. Hermans \& T. Gieser (Eds.), Handbook of dialogical self theory (pp. 241-252). Cambridge University Press.

Oyserman, D. (2004). Self-concept and identity. In M. B. Brewer \& M. Hewstone (Eds.), Self and social identity (pp. 5-24). Blackwell.

Read, S. J., Smith, B. J., Droutman, V., \& Miller, L. C. (2017). Virtual personalities: Using computational modeling to understand within-person variability. Journal of Research in Personality, 69, 237-249. https://doi.org/10.1016/j.jrp.2016.10.005

Rosenberg, S. (1997). Multiplicity of selves. In R. D. Ashmore \& L. J. Jussim (Eds.), Rutgers series on self and 
social identity, Vol. 1. Self and identity: Fundamental issues (pp. 23-45). Oxford University Press.

Ross, C. A. (1999). Subpersonalities and multiple personalities: a dissociative continuum? In J. Rowan \& M. Cooper (Eds.), The plural self. Multiplicity in everyday life (pp. 183-197). Sage.

Ross, C. A., Ellason, J. W., \& Anderson, G. (1995). A factor analysis of the Dissociative Experiences Scale (DES) in dissociative identity disorder. Dissociation, 8, 229-235.

Schmitt, D. P., Allik, J., McCrae, R. R., \& BenetMartínez, V. (2007). The geographic distribution of Big Five personality traits. Journal of CrossCultural Psychology, 38, 173-212. https://doi.org/ 10.1177/0022022106297299

Schwartz, R. (1999). The internal family systems model. In J. Rowan \& M. Cooper (Eds.), The plural self. Multiplicity in everyday life (pp. 238-253). Sage.

Scott, W. A. (1966). Brief report: Measures of cognitive structure. Multivariate Behavioral Research, 1, 3741. https://doi.org/10.1207/s15327906mbr0103_9

Siuta, J. (1989). Zmienna aprobaty społecznej w badaniach nad zjawiskami hipnotycznymi [A variable of social approval in research on hypnotic phenomena]. Zeszyty Naukowe Uniwersytetu Jagiellońskiego, 5, 131-141.

Stone, H., \& Stone, S. (1993), Embracing our selves: The voice dialogue manual. Nataraj Publishing.

Styła, R., Jankowski, K., \& Suszek, H. (2010). Skala niespójności Ja (SN-Ja) [Self-Concept Inconsistency Scale]. Studia Psychologiczne, 48, 31-43.

Suszek, H. (2005). Wielość Ja w społeczeństwie postmodernistycznym [Self-pluralism in postmodern society]. Psychologia. Edukacja i Spoteczeństwo, 2, 57-70.

Tajfel, H., \& Turner, J. C. (1979). An integrative theory of intergroup conflict. In W. G. Austin \& S. Worchel (Eds.), The social psychology of intergroup relations (pp. 33-47). Brooks-Cole.

Triandis, H. C. (1989). The self and social behavior in differing cultural contexts. Psychological Review, 96, 506-520. https://doi.org/10.1037/0033-295X.96.3.506

Wilson, R. E., Thompson, R. J., \& Vazire, S. (2017). Are fluctuations in personality states more than fluctuations in affect? Journal of Research in Personality, 69, 110-123. https://doi.org/10.1016/j.jrp.2016. 06.006

Zawadzki, B., Strelau, J., Szczepaniak, P., \& Śliwińska, M. (1998). Inwentarz osobowości NEO-FFI Costy i McCrae. Polska adaptacja [The NEO-FFI inventory by Costa and McCrae. Polish adaptation]. Pracownia Testów Psychologicznych PTP.

Zawisza, M., Luyt, R., \& Zawadzka, A. M. (2012). Ambivalence toward men: Comparing sexism among Polish, South African and British university students. Sex Roles, 66, 453-467. https://doi.org/ 10.1007/s11199-011-0112-4 